\title{
大腿骨頝部骨折の骨折型発症に影響を及ぼす因子について
}

\author{
博愛病院整形外科 \\ 中 村達彦・高田尚文
}

\section{Risk Factors Related to Type of Proximal Femoral Fractures}

by

Tatsuhiko Nakamura and Takafumi Takata

Department of Orthopaedic Surgery, Hakuai Hospital, Yonago, Japan

\begin{abstract}
There are two types of porximal femoral fractures; cervical and trochanteric. The risk factors related to these types of fractures were examined. 15 women aged 66 to 99 (mean age; 81.5 years) with cervical fractures and age- and sex-matched controls aged 73 to 95 (mean age; 82.7 years) with trochanteric fractures were analyzed by the Wilcoxon signed-ranks test. Height, weight and body mass index were not considered risk factors. The bone mineral density of the neck region divided by that of the trochanteric region (NT value) was a significant risk factor. The average NT value was 1.27 for cervical fractures and 1.57 for trochanteric ones. The neck axis length (NAL) of the proximal femur was also a significant risk factor. The average NAL was $10.3 \mathrm{~cm}$ for cervical fractures and $9.6 \mathrm{~cm}$ for trochanteric.
\end{abstract}

Key words : Femoral neck fracture (大腿骨頚部骨折), Bone mineral density（骨密度), Neck axis lenght (大腿骨䅡部長)

はじめに

大腿骨頝部骨折は解剖学的に関節包内骨折 (以下内 側骨折）及び関節包外骨折（以下外側骨折）に分ける ことが出来る. そして, 両者の発生率は年代別に異な り,また内外側の発生比す人種的に異なることが知ら れている゙．そこで今回我々はまず日本人女性におい て, 年齢を合わせた内側骨折群と外側骨折群とを比較 し, 内外側骨折型発症に影響を及ぼす因子について検 討した。

\section{対象および方法}

対象は全例女性で内側骨折患者 15 例（年齢 66 99 歳，平均年齢 81.5 歳）及び性，年齢を合わせた外側 骨折患者 15 例（年齢 73 95 歳, 平均年齢 82.7 歳） とした. 検討因子は身長, 体重, Body mass index (以下 BMI), 健倒の大腿骨䅡部骨量及び健側大腿骨
頝部長 Neck axis length（以下 NAL）とした. 検定 はWilocoxon の符号付順位和検定を用いた。骨量測 定は受傷後可及的早期に Hologic QDR 1000 plus を 用い, Neck 領域, Trochanter 領域及び Ward's 領 域を測定した。 また， Neck 領域の骨量値を Trochanter 領域の骨量值で割った值（以下 NT 值）す求 めて検討した. NAL は大腿骨䅡部の中央を通る直線 が大腿骨頭及び外側皮質と交差する間の長さをレント ゲン写真正面像から計測し求めた.

\section{結果}

各検討因子の平均値を表 1 に示す。身長, 体重, BMI で有意な差は見られなかった。

Neck 領域の骨量では有意な差はみられなかった。 Trochanter 領域の骨量は, 外側骨折群の方が低い値 を示す傾向にあったが，有意な差はみられなかった。 Ward's 領域の骨量でも外側骨折群の方が低い值を示 
表 1 大腿骨頚部内側骨折女性患者と年齢を合わせた外側骨

\begin{tabular}{lcc}
\hline \hline & 内側骨折 $(\mathrm{n}=15)$ & 外側骨折 $(\mathrm{n}=15)$ \\
\hline 身長 $(\mathrm{cm})$ & 149.9 & 147.9 \\
体重 $(\mathrm{kg})$ & 45.7 & 41.7 \\
BMI & 20.3 & 19.2 \\
骨量 $\left(\mathrm{mg} / \mathrm{cm}^{2}\right)$ & & \\
Neck 領域 & 473.7 & 481.0 \\
Trochanter 領域 & 388.5 & 327.9 \\
Ward's 領域 & 227.1 & 255.9 \\
NT 值 & 1.27 & $1.57^{*}$ \\
NAL (cm) & 10.3 & $9.6^{*}$ \\
\hline
\end{tabular}

BMI (body mass imdex) : 体重 $(\mathrm{kg}) /$ 身長 $(\mathrm{cm})^{2} \times 10^{4}$ NT 值 : Neck 領域の骨量/Trochanter 領域の骨量 NAL : neck axis length (大腿骨頚部長) $\cdot \mathrm{p}<0.05$ Wilcoxon の符号付順位和検定

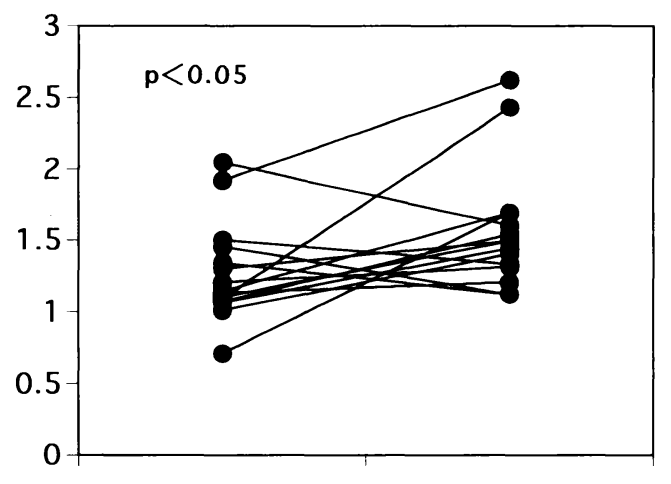

内側骨折

外側骨折

図 1 NT 值 (Neck 領域の骨量値を Trochanter 領域の骨 量値で割った値) の比較

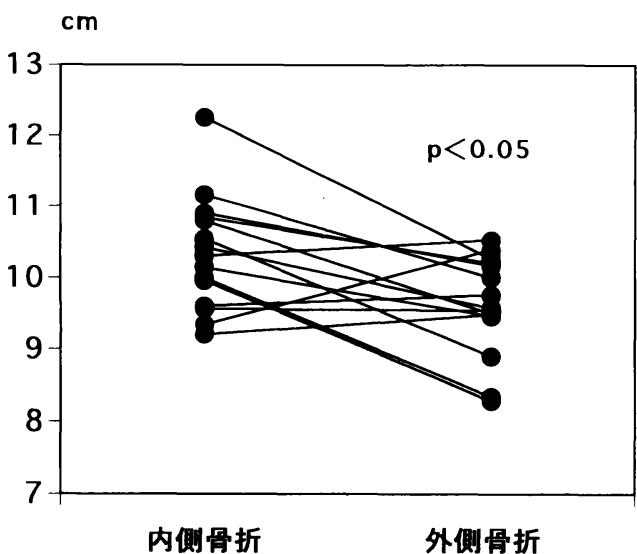

図 2 大腿骨頚部長 (Neck axis length : NAL) の比較
す傾向にあったが有意な差は見られなかった.

NT 值は内側骨折群が外側骨折群よりも有意に小さ く, 骨量分布が内外側骨折型の発症に関連しているこ とが分かった（図 1 ).

NAL は内側骨折群が外側骨折群よりあ有意に長く 頚部の形態も内外側骨折型発症に関連していることが 分かった（図2）.

考 察

大腿骨近位部骨量については藤原ら ${ }^{2)}$ 我々の結果 之同様に, Neck 領域の骨量は内側骨折群が外側骨折 群よりも少なく，Trochanter 領域の骨量は外側骨折 群が内側骨折群よりあ少ないと報告している. しかし いずれす，有意な差は見られていない。 そこで， Neck 領域の骨量值を Trochanter 領域の骨量值で割っ た値を NT 值として検討した結果，有意な差を得る ことが出来た.

大腿骨頚部長について諸家の報告をみると，Ferris ら”は我々と同様に内側骨折群の方が外側骨折群より 頝部長が長いという結果を示しているが, 今井ら ${ }^{3)}$ は 両骨折間に有意差は無いと報告している. 内外側骨折 間で年齢を合わせていないという点では Ferris らと 同様であることから，測定方法により影響が生じてい ると考えた.

$$
\text { ま と め }
$$

1. 大腿骨頝部骨折の骨折型発症に影響を及ぼす因 子について検討した.

2. Neck 領域の骨量値を Trochanter 領域の骨量 值で割った値（NT 值）は内側骨折群の方が外側骨折 群よりも有意に小さく，骨量分布が内外側骨折型の発 症に関連する因子であることが分かった.

3. 大腿骨頚部長 (Neck axis length : NAL) は 内側骨折群が外側骨折群よりも有意に長く頝部の形態 あ内外側骨折型発症に関連する因子であることが分かっ た. 


\section{參考文 献}

1) Ferris, $\mathrm{BD}$ et al. : Morphology of the femur in proximal femoral fractures. J. Bone Joint Surg., 71-B : 475477, 1989.

2）藤原敏弘他 : 大腿骨近位部骨塩量の検討一大腿骨頚部
骨折之骨塩量一。目骨代謝誌， $7 ： 188 ， 1989$.

3）今井弘子他 : Dual-energy X-ray Absorptiometry に よる Hip Axis Length の測定 : 頚部骨折と転子部骨折の 比較. 日整会誌, $70: s 797,1996$.

4）中村達彦: 鳥取県における大腿骨頚部骨折の疫学的研 究. 日整会誌, $67: 189-200,1993$. 